\title{
Kelayakan Perubahan Kelas Perusahaan: Studi Kasus di Bagian Hutan Ngantang Pujon, KPH Malang \\ (Feasibility of change in Enterprise Class: Case Study in the Forest Section of Ngantang Pujon, KPH Malang)
}

\section{Ikhlasul Amalias Firdani*, Mochammad Chanan, dan/and Galit Gatut Prakosa}

\author{
Jurusan Kehutanan, Fakultas Pertanian-Peternakan, Universitas Muhammadiyah Malang Jln. Raya Tlogomas \\ No. 246, Tlogomas, Malang, Jawa Timur 65144 \\ Tlp. (0341) 63513; Fax. (0341) 460435 E-mail: fpp@umm.ac.id \\ *E-mail : dhaniamalia19@gmail.com
}

Tgl diterima: 30 Agustus 2021; Tgl disetujui: 1 Desember 2021; Tgl direvisi: 2 Desember 2021

\begin{abstract}
The decline in damar stands due to shoot death has caused losses to the company. To anticipate these problems, it is necessary to find a enterprise class that is suitable with site characteristics. This study aimed to determine the business feasibility of damar and pine plants in order to determine the right enterprise class. The research was conducted in the Ngantang Pujon Forest Section, KPH Malang. The method used is quantitative descriptive using primary and secondary data. The analysis used is business feasibility analysis by calculating the Net Present Value (NPV), Benefit Cost Ratio (BCR), and Internal Rate Return (IRR). The results of NPV analysis showed that both damar and pine companies are feasible to cultivate. The pine enterprise class has a higher eligibility than the damar enterprise class. Thus, financially, the damar enterprise class can be changed to the pine enterprise class.
\end{abstract}

Keywords : Firm grade, financial, stand, pine, damar

\begin{abstract}
Abstrak
Penurunan tegakan damar akibat mati pucuk telah menimbulkan kerugian bagi perusahaan. Untuk mengantisipasi permasalahan tersebut perlu dicarikan kelas perusahaan yang sesuai dengan karakteristik tapak. Tujuan penelitian adalah mengetahui kelayakan usaha tanaman damar dan pinus guna menentukan kelas perusahaan yang tepat. Penelitian dilaksanakan di Bagian Hutan Ngantang Pujon, KPH Malang. Metode yang digunakan yaitu deskriptif kuantitatif menggunakan data primer dan sekunder. Analisis yang digunakan adalah analisis kelayakan usaha dengan menentukan nilai Net Present Value (NPV), Benefit Cost Ratio (BCR), dan Internal Rate Return (IRR). Hasil analisis NPV menunjukkan kedua kelas perusahaan damar dan pinus layak diusahakan. Kelas perusahaan pinus kelayakannya lebih tinggi daripada kelas perusahaan damar. Secara finansial kelas perusahaan damar dapat dirubah menjadi kelas perusahaan pinus.
\end{abstract}

Kata kunci : Kelas perusahaan, finansial, tegakan, pinus, damar 


\section{Pendahuluan}

Perusahaan hutan memiliki beberapa sifat khas yang membedakannya dengan jenis perusahaan atau bentuk pemanfaatan lahan lainnya. Berdasarkan Peraturan Pemerintah Nomor 23 tahun 2021 tentang penyelengaraan kehutanan menyatakan bahwa PT Perhutani mendapatkan penugasan dari pemerintah untuk melakukan pengelolaan hutan berdasarkan prinsip pengelolaan hutan lestari (PHL) dan prinsip tata kelola perusahaan yang baik, wajib melakukan pencegahan dan pengamanan hutan di areal kelolanya. Menurut Purbawiyatna, Kartodiharjo, Alikodra, \& Prasetyo (2011) konsep pengelolaan hutan lestari didasarkan atas terpenuhinya kelestarian tiga fungsi utama hutan, yaitu fungsi ekologis, lingkungan, dan fungsi sosial ekonomi. Pada dasarnya pengelolaan hutan harus memenuhi ketiga aspek tersebut agar hutan tetap terjaga kelestariannya.

Areal PT Perhutani khususnya kawasan Kesatuan Pengelolaan Hutan (KPH) Malang di Bagian Hutan Ngantang Pujon melakukan pengelolaan hutan dengan kelas perusahaan tanaman damar (Aghatis dammara (Lamb.) Rich.). Luas kawasan tanaman damar (A. dammara) berdasarkan jangka RPKH tahun 1991 - 2000 sebesar $2.399,10$ ha. Pengelolaan hasil hutan tanaman damar berupa hasil hutan kayu dan non kayu. Manfaat utama damar adalah diambil getahnya untuk diolah menjadi kopal. Kopal ini mengandung asam-asam resinol, resin, dan minyak atsiri yang bernilai ekonomi (Antoh, Fatem, \& Tasik, 2015).

Begitu juga tanaman pinus dapat menghasilkan kayu dan getah pinus disadap untuk berbagai produk antara lain gondorukem dan terpentin yang bernilai tinggi (Iriando, Sadly, Haneda, \& Farikhah, 2011). Kebutuhan pasar produk berbahan baku getah pinus, termasuk jenis alphapinene dan bethapinene di dunia mencapai 600.000 ton per tahun, sedangkan di dalam negeri mencapai 19.000 ton per tahun (Perhutani, 2014).

Pada jangka Rencana Pengelolaan Kawasan Hutan (RKPH) periode 2001 2010 luas tegakan damar berkurang 70,41\% dari jangka RPKH periode 1991 - 2000 menjadi 709,90 ha sementara pada periode 2011 - 2020 terjadi penurunan luasan sebesar 15,86\% dari jangka sebelumnya. Pengurangan hutan tanaman damar terjadi akibat tegakan damar di usia muda mengalami mati pucuk. Hal ini berdampak pada hasil pemanenan dari kelas hutan produktif. Tegakan damar seharusnya lebih mendominasi sebagai penghasil terbesar pada kelas perusahaan di Bagian Hutan Ngantang Pujon, KPH Malang (PHW IV Malang, 2018).

Tegakan damar yang mati digantikan dengan tanaman pinus (Pinus merkusii Jungh. at de Vriese). Hal ini menyebabkan jumlah tegakan pinus lebih besar daripada tegakan damar. Perubahan kelas perusahaan damar menjadi kelas perusahaan pinus perlu dianalisis terlebih dahulu dengan melakukan perbandingan penilaian kelayakan usahanya. Hal ini sesuai dengan pendapat Soedomo \& Kartodiharjo (2011) bahwa pengelolaan hutan yang baik memerlukan perencanaan yang baik berdasarkan hasil kelayakan usahanya.

Apabila struktur hutan normal dipertahankan dalam jangka yang panjang, maka akan memberikan hasil yang berkelanjutan. Dari hasil analisis tersebut dapat dilihat apakah usaha tersebut dapat memberikan hasil yang optimal baik dari segi keuangan maupun dari segi kelestarian hasil hutan (Rohman, Warsito, Purwanto, \& Suprayatno, 2013). Tujuan analisis ini adalah melakukan evaluasi kelayakan secara finansial antara kelas perusahaan damar dengan kelas perusahaan pinus di Bagian Hutan Ngatang dan Pujon, KPH Malang. 


\section{Metodologi}

\subsection{Waktu dan Lokasi Penelitian}

Penelitian dilaksanakan selama lima bulan yaitu bulan September 2020 - Januari 2021. Penelitian dilaksanakan di Bagian Hutan Ngantang Pujon, KPH Malang, yaitu di BKPH Ngantang (RPH Ngantang, RPH Kasembon, RPH Sekar) dan BKPH Pujon (RPH Pujon Utara, dan RPH Kedungrejo). Secara administratif lokasi penelitian berada di Kabupaten Malang. Lokasi penelitian disajikan pada Gambar 1.

\subsection{Metode}

Bahan yang digunakan dalam penelitian ini antara lain yaitu buku RPKH kelas perusahaan damar Bagian Hutan Ngantang dan Pujon dan tabel harga dasar biaya produksi per hektar. Berdasarkan buku RPHK diperoleh data nilai biaya produksi dan pendapatan, yaitu: luas persemaian, penanaman, pemeliharaan, dan penjarangan, serta data pendapatan dari luas tebangan dan pemanenan getah antara kelas perusahaan damar dan pinus. Alat yang digunakan dalam penelitian ini adalah laptop dan pengolah data (microsoft excel), kamera digital, dan alat pendukung lainnya.

\subsubsection{Tahap pelaksanaan}

Tahap pelaksanaan penelitian dilakukan dengan mengumpulkan data keuangan dari hasil pengelolaan hutan tanaman damar dan pinus. Data yang diperoleh berupa data cost and benefit dari proyek kelas perusahaan damar dan pinus. Analisis kelayakan usaha ditujukan untuk mendapatkan informasi layak atau tidaknya suatu usaha untuk dijalankan. Untuk analisis tersebut digunakan kriteria nilai NPV, BCR dan IRR. Selanjutnya dibandingkan kelayakan usahanya berdasarkan hasil analisis antara kelas perusahaan damar dengan pinus.

\subsubsection{Analisis data}

Analisis kelayakan usaha menggunakan data biaya produksi (persemaian, penanaman, pemupukan, pemeliharaan, penjarangan, dan pemanenan) dan data pendapatan (hasil hutan kayu dan getah). Beberapa kriteria yang digunakan untuk menilai kelayakan usaha adalah Net Present Value (NPV), Internal Rate of Return (IRR), dan Benefit Cost Ratio (BCR). Suatu usaha dapat dikatakan layak untuk dijalankan dengan ketentuan NPV $\geq 0$, IRR $>$ discount rate social, dan BCR > 1 (Arianti, Idham \&, Zainal, 2018).

NPV diperoleh dengan cara mendiskontokan selisih antara jumlah kas yang keluar dari dana proyek dan kas yang masuk ke dalam dana proyek tiap tahun, dengan satu tingkat persentase bunga yang telah ditentukan sebelumnya (Sutojo, 2007). Jika NPV $\geq 0$, berarti proyek tersebut mengembalikan persis sebesar "social opportunity cost of capital" artinya usaha tersebut layak. Jika NPV < 0, berarti proyek ditolak atau usaha tidak layak, artinya ada penggunaan lain yang lebih menguntungkan untuk sumber-sumber yang diperlukan proyek. Rumus NPV sebagai berikut:

$N P V=\sum_{t-1}^{n} \frac{B t-C t}{(1+t)^{i}}$

Dimana:

$\mathrm{Bt}=$ Pendapatan kotor pada tahun ke-t;

$\mathrm{Ct}=$ Biaya kotor pada tahun ke-t;

$\mathrm{n}=$ Umur proyek;

$\mathrm{t}=$ Interval waktu; dan

$\mathrm{i}=$ Tingkat suku bunga bank. 


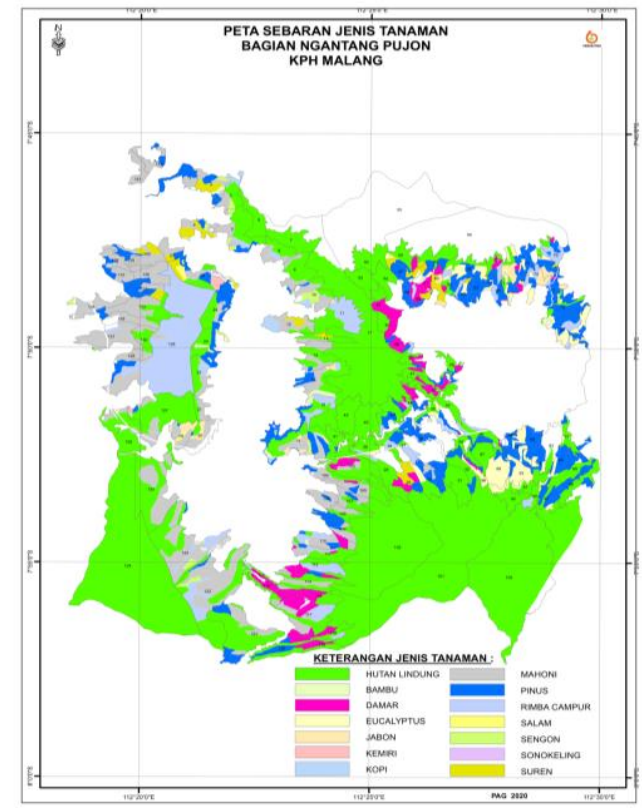

Gambar (Figure) 1. Peta kawasan Bagian Hutan Ngantang Pujon, KPH Malang (Map of the Ngantang Pujon Forest Section, KPH Malang)

NPV diperoleh dengan cara mendiskontokan selisih antara jumlah kas yang keluar dari dana proyek dan kas yang masuk ke dalam dana proyek tiap tahun, dengan satu tingkat persentase bunga yang telah ditentukan sebelumnya (Sutojo, 2007). Jika NPV $\geq 0$, berarti proyek tersebut mengembalikan persis sebesar "social opportunity cost of capital" artinya usaha tersebut layak. Jika NPV < 0, berarti proyek ditolak atau usaha tidak layak, artinya ada penggunaan lain yang lebih menguntungkan untuk sumber-sumber yang diperlukan proyek. Rumus NPV sebagai berikut:

$$
N P V=\sum_{t-1}^{n} \frac{B t-C t}{(1+t)^{i}}
$$

Dimana:

$\mathrm{Bt}=$ Pendapatan kotor pada tahun ke-t;

$\mathrm{Ct}=$ Biaya kotor pada tahun ke-t;

$\mathrm{n}$ = Umur proyek;

$\mathrm{t}$ = Interval waktu; dan

$\mathrm{i}=$ Tingkat suku bunga bank.

IRR adalah tingkat suku bunga bank yang dipergunakan untuk mendiskonto seluruh selisih kas masuk pada tahun-tahun operasi proyek yang akan menghasilkan sejumlah kas yang sama dengan jumlah investasi proyek (Khotimah \& Sutiono, 2015). Pada dasarnya IRR menggambarkan persentase laba nyata yang dihasilkan proyek. Besaran " $i$ " yang menjadikan NPV $=0$, itulah yang disebut IRR dari suatu proyek. Kriteria untuk menetapkan kelayakan suatu proyek apabila IRR lebih besar dari discount rate (tingkat bunga), atau IRR > i (Krisnawan, Warsika, \& Nadiasa. 2015).

$I R R=i_{1}+\frac{N P V_{1}}{N P V_{1}-N P V_{2}}\left(i_{2}-i_{1}\right)$

Dimana:

$\mathrm{i}_{1} \quad=$ Nilai percobaan pertama untuk suku bunga i;

$\mathrm{i}_{2}=$ Nilai percobaan kedua untuk suku bunga $\mathrm{i}$;

$\mathrm{NPV}_{1}=$ Nilai NPV untuk percobaan pertama;

$\mathrm{NPV}_{2}=$ Nilai NPV untuk percobaan kedua.

BCR merupakan besarnya nilai hasil perbandingan antara total pendapatan yang telah didiskonto dengan nilai biaya total 
yang telah didiskonto. Apabila BCR > 1 berarti NPV $>0$ artinya usaha tersebut layak untuk dijalankan (Majarani, 2006). Rumus dari BCR sebagai berikut:

$$
B C R=\frac{\sum_{t-1}^{n} \frac{B t}{(1+t)^{i}}}{\sum_{t-1}^{n} \frac{C t}{(1+t)^{i}}}
$$

Dimana:

$\mathrm{Bt}=$ Pendapatan kotor pada tahun ke-t;

$\mathrm{Ct}=$ Biaya kotor pada tahun ke-t;

$\mathrm{n}=$ Umur proyek; $\mathrm{t}=$ interval waktu; dan

$\mathrm{i} \quad=$ Tingkat suku bunga bank.

\section{Hasil dan Pembahasan}

\subsection{Hasil}

Bagian Hutan Ngantang Pujon terdiri dari dua BKPH dan enam RPH, yaitu BKPH Ngantang dan Pujon. BKPH Ngantang terdiri dari RPH Ngantang, RPH Sekar, dan RPH Kasembon. Sedangkan di BKPH Pujon terdiri RPH Pujon Utara, RPH Pujon Selatan, dan RPH Kedungrejo.

\subsubsection{Biaya produksi}

Biaya sejak penanaman hingga penebangan dilakukan dengan nilai uang pada saat daur berakhir. Biaya yang dikeluarkan diantaranya biaya persemaian, biaya penanaman, biaya pemeliharaan, biaya penjarangan, dan biaya pemanenan. Total biaya yang dikeluarkan dihitung selama jangka waktu satu daur RPKH (Tabel 1). Biaya ini didapatkan dari hasil perhitungan biaya yang dikeluarkan per satuan hektar. Biaya di setiap tahun tidak selalu sama, yaitu ada kegiatan yang mengalami kenaikan dan ada yang mengalami penurunan.

Tabel 1 menunjukkan bahwa total biaya produksi kelas perusahaan pinus ternyata lebih besar dibandingkan dengan kelas perusahaan damar, dalam jangka satu daur RPKH.

\subsubsection{Pendapatan}

Pendapatan dari proyek diestimasikan dari pendapatan hasil panen getah dan kayu. Pendapatan dari hasil pemanenan kayu menggunakan harga berlaku saat ini. Di Bagian Hutan Ngantang Pujon ini memiliki dua penghasilan getah, yaitu getah pinus dan getah damar (Tabel 2).

Pendapatan pada Tabel 2 diperoleh dari hasil sadap getah pinus tertinggi selama masa jangka RPKH. Pendapatan dari penyadapan getah berbeda jauh antara hasil sadapan pinus dengan sadapan damar. Hal ini dikarenakan jumlah luasan sadapan pinus lebih banyak daripada sadapan damar. Dari Tabel 2, pendapatan dari hasil sadapan getah pinus tertinggi selama masa jangka RPKH, namun hasil tebangan kayu damar lebih tinggi daripada hasil tebangan pinus. Jika digabungkan pendapatan dari hasil tebangan dan hasil sadapan, maka pendapatan dari proyek tanaman pinus lebih tinggi daripada tanaman damar.

Selanjutnya dilakukan analisis kelayakan usaha dengan analisis finansial dari perubahan kelas perusahaan damar dan pinus. Perubahan kelas perusahaan damar menjadi kelas perusahaan pinus dikatakan layak, jika memenuhi beberapa kriteria kelayakan finansial.

Hasil analisis finansial menunjukkan bahwa nilai NPV, BCR, dan IRR dari usaha pinus lebih besar daripada usaha damar. Berdasarkan kriteria analisis finansial nilai, $\mathrm{NPV} \geq 0, \mathrm{BCR}>1$, dan IRR di atas suku bunga bank (Tabel 3). Kedua kelas perusahaan damar dan pinus layak. Apabila dibandingkan antara kelas perusahaan damar dengan kelas perusahaan pinus, maka kelas perusahaan pinus lebih layak daripada kelas perusahaan damar. 
Tabel (Table) 1. Total biaya produksi (Total production cost)

\begin{tabular}{crr}
\hline \multirow{2}{*}{ Tahun } & \multicolumn{2}{c}{ Total biaya produksi untuk kelas perusahaan (Total production cost for } \\
\cline { 2 - 3 } (Year) & \multicolumn{2}{c}{ enterprise class) (Rp) } \\
\hline 0 & Damar (Damar) & Pinus (Pine) \\
1 & 76.247 .600 & 103.909 .520 \\
2 & 146.274 .450 & 14.712 .740 \\
3 & 1.824 .234 .270 & 3.812 .252 .210 \\
4 & 927.816 .675 & 964.566 .400 \\
5 & 137.168 .020 & 443.546 .890 \\
6 & 49.662 .845 & 184.390 .355 \\
7 & - & 1.603 .830 \\
8 & 69.642 .440 & 7.595 .980 \\
9 & 3.505 .360 & 17.237 .240 \\
10 & - & - \\
\hline Total & 11.932 .050 & 21.504 .225 \\
\hline
\end{tabular}

Sumber (Source): Hasil analisis (Analysis result), (2020)

Tabel (Table) 2. Estimasi pendapatan (Estimated Income)

\begin{tabular}{crrrr}
\hline & \multicolumn{2}{c}{ Hasil pinus (Pine yield) (Rp.) } & \multicolumn{2}{c}{ Hasil damar (Damar yield) (Rp.) } \\
\cline { 2 - 5 } Tahun (Year) & $\begin{array}{c}\text { Hasil tebangan } \\
\text { (Felling) }\end{array}$ & $\begin{array}{c}\text { Hasil penyadapan } \\
\text { (Sap tapping } \\
\text { yield) }\end{array}$ & $\begin{array}{c}\text { Hasil } \\
\text { tebangan } \\
\text { (Felling) }\end{array}$ & $\begin{array}{c}\text { Hasil penyadapan } \\
\text { (Sap tapping } \\
\text { yield) }\end{array}$ \\
\hline 2011 & 262.715 .880 & 1.331 .180 & 1.647 .320 .590 & 7.216 .000 \\
2012 & 161.486 .340 & 1.650 .002 & 3.345 .850 & 16.416 .000 \\
2013 & 51.919 .860 & 1.174 .261 & 7.094 .990 & 13.512 .000 \\
2014 & 2.536 .390 & 1.639 .582 .000 & 527.840 & 15.696 .000 \\
2015 & 120.514 .420 & 1.685 .491 .500 & 719.780 & 14.100 .000 \\
2016 & 6.726 .460 & 1.214 .286 .500 & - & 14.580 .000 \\
2017 & 155.234 .600 & 1.313 .942 .000 & 1.990 .473 .230 & 18.140 .000 \\
2018 & 85.815 .920 & 1.336 .517 .000 & 88.506 .060 & 18.152 .000 \\
2019 & - & 1.103 .112 .500 & & - \\
2020 & - & 711.242 .000 & 18.168 .000 & 18.168 .000 \\
\hline Total & 846.949 .870 & 9.008 .328 .942 & 3.756 .156 .340 & 148.756 .000 \\
\hline
\end{tabular}

Sumber (Source): Hasil analisis (Analysis result), (2020) 
Tabel (Table) 3. Hasil perhitungan NPV, BCR dan IRR (NPV, BCR and IRR Calculation Results)

\begin{tabular}{|c|c|c|c|c|c|}
\hline No & $\begin{array}{l}\text { Analisis } \\
\text { (Analysis) }\end{array}$ & $\begin{array}{c}\text { Kriteria } \\
\text { kelayakan } \\
\text { (Eligibility } \\
\text { criteria) }\end{array}$ & $\begin{array}{l}\text { Kriteria pinus } \\
\text { (Pine criteria) }\end{array}$ & $\begin{array}{l}\text { Kriteria damar } \\
\text { (Damar criteria) }\end{array}$ & $\begin{array}{l}\text { Keputusan } \\
\text { (Decision) }\end{array}$ \\
\hline 1. & $\begin{array}{l}\text { Net Present } \\
\text { Value (NPV) }\end{array}$ & $\geq 0$ & 1.064 .730 .697 & 77.131 .713 & $\begin{array}{l}\text { Kriteria } \\
\text { pinus layak } \\
\text { (Pine } \\
\text { feasible) }\end{array}$ \\
\hline 2. & $\begin{array}{l}\text { Benefit Cost } \\
\text { Ratio (BCR) }\end{array}$ & $>1$ & 1,24 & 1,03 & $\begin{array}{l}\text { Kriteria } \\
\text { pinus layak } \\
\text { (Pine } \\
\text { feasible) }\end{array}$ \\
\hline 3. & $\begin{array}{l}\text { Internal Rate } \\
\text { of Return } \\
\text { (IRR) }\end{array}$ & $\begin{array}{c}\text { > Suku bunga } \\
\text { (Interest rate) } \\
(10 \%)\end{array}$ & $17 \%$ & $13 \%$ & $\begin{array}{l}\text { Kriteria } \\
\text { pinus layak } \\
\text { (Pine } \\
\text { feasible) }\end{array}$ \\
\hline
\end{tabular}

Sumber (Source) : Hasil analisis (Analysis result), (2020)

\subsection{Pembahasan}

Bagian Hutan Ngantang Pujon pada jangka RPKH 2011 - 2020 memiliki kelas perusahaan damar. Saat ini terjadi perubahan struktur tegakan dikarenakan tanaman muda damar di Bagian Hutan Ngantang Pujon mengalami mati pucuk di lapangan. Penyebab mati pucuk pada tegakan damar yang masih muda. Menurut Wattimena, Pelupessy, \& Selang (2016) penyebab kerusakan tanaman muda pada damar dikarenakan serangan hama belalang kayu (Valanga nigricormis) yang memakan daging daun damar, sehingga menyebabkan tanaman muda rusak dan mati. Hal ini dapat mengakibatkan kegagalan usaha pembangunan hutan tanaman damar di KPH Malang. Menurut Riyanto, Waluya, \& Pahala (2012), perubahan dinamika sumber daya hutan juga terjadi di hutan jati PT Perhutani, sebagai akibat gangguan yang ditimbulkan dari interaksi hutan dengan faktor sosial ekonomi, serta faktor pengelolaan. Faktor sosial ekonomi diantaranya yaitu, pencurian/ penjarahan, penggembalaan liar dan kebakaran.

Seiring terjadinya perubahan struktur tegakan damar yang semakin berkurang, maka dilakukan pergantian kelas perusahaan tanaman damar menjadi tanaman pinus. Pemilihan tanaman pinus sebagai kelas perusahaan dikarenakan pendapatan dari hasil getah dan tebangan cukup tinggi, dan memiliki peluang ekspor produk getah pinus yang tinggi. terdapat kecenderungan peningkatan permintaan dunia terhadap komoditi getah pinus di masa yang akan datang (Ishak, 2018). Upaya untuk meningkatkan produksi getah melalui perluasan lahan tanaman pinus merupakan langkah untuk pemanfaatan hutan yang dapat menyerap tenaga kerja di sekitar hutan dan sekaligus menambah devisa bagi negara.

Perubahan kelas perusahaan dilakukan untuk memenuhi aspek kelestarian hutan dengan melakukan analisis antara kelayakan usaha damar dengan pinus. Dari hasil analisis NPV, BCR, dan IRR ternyata kelas perusahaan pinus layak untuk menggantikan kelas perusahaan damar. Jika dilihat dari nilai NPV, kedua kelas perusahaan tersebut memiliki nilai NPV $\geq 0$, artinya usaha tanaman pinus dan damar layak. Nilai NPV pinus memiliki nilai lebih besar daripada NPV damar. Hal ini menunjukkan usaha hutan tanaman pinus lebih menguntungkan 
daripada usaha hutan tanaman damar (Kusuma \& Mayasti, 2014). Menurut Subarudi (2014) usaha pengelolaan hutan akan menguntungkan karena manfaat yang diterima proyek lebih besar dari semua biaya total yang dikeluarkan. Hasil perhitungan NPV ini juga menunjukkan besar keuntungan bersih yang diperoleh bernilai positif selama satu periode. Berdasarkan analisis nilai IRR menunjukkan bahwa nilai IRR pinus (17\%) lebih besar daripada IRR damar (13\%). Nilai IRR kelas perusahaan damar dan pinus berada di atas suku bunga bank (investasi) (10\%). Menurut Efendi (2016) tingkat suku bunga yang berlaku di Bank Indonesia dan suku bunga rata-rata yang berlaku pada bank-bank pemerintah maupun bank swasta saat ini berkisar $12-18 \%$ per tahun.

Pengelolaan hutan tanaman yang menghasilkan kayu dan hasil hutan bukan kayu menarik untuk dikembangkan di hutan tanaman. Seperti pengelolahan hutan pada usaha jati dan mahoni pemanfaatannya hanya berupa kayu. Kegiatan produksinya membutuhkan waktu yang lama untuk memasuki masa masak tebang, yaitu daur jati 30 tahun dan daur mahoni 19 tahun. Selama menunggu masak tebang kayu jati dan mahoni tidak dilakukan pemanfaatan, sehingga PT. Perhutani tidak mendapatkan keuntungan. Hutan tanaman pinus pada umur 11 tahun dapat dilakukan penyadapan getah sampai umur pinus 50 tahun dan sekaligus dilakukan penebangan (Inayati, 2015).

Dampak adanya perubahan kelas perusahaan tanaman damar menjadi pinus secara sosial dapat dirasakan oleh masyarakat sekitar hutan terutama pesanggem, tanaman pinus lebih disukai pesanggem, sehingga tingkat keberhasilan tanaman akan meningkat dan pendapatan dari hasil sadapan serta pesanggem dapat mengolah lahan di bawah tegakan tanaman pinus (Gaol, 2020). Secara ekologi adanya tegakan akan mampu menahan erosi tanah dan penyerapan karbon. Adanya tambahan pendapatan dari getah, maka akan menambah profit perusahaan dari hasil sadapan (Ikramatoun, Khairulyadi, \& Riduan, 2020). Tegakan pinus memiliki stok karbon yang tinggi dibandingkan dengan damar maupun mahoni. Hal ini menunjukan semakin banyak jumlah tanaman pinus akan meningkatkan jumlah karbon di udara. Kerapatan tegakan pinus berpengaruh terhadap jumlah karbon yang dihasilkan (Heriyanto, Wibowo, \& Garsetiasih, 2010).

\section{Kesimpulan dan Saran}

\subsection{Kesimpulan}

Secara finansial, kelas perusahaan damar layak diganti menjadi kelas perusahaan pinus. Hal ini diketahui dari hasil analisis yang menunjukkan bahwa nilai NPV, BCR dan IRR kelas perusahaan pinus lebih tinggi daripada kelas perusahaan damar. Nilai NPV kelas usaha pinus Rp 1.064.730.697,00, sedangkan NPV kelas perusahaan damar $\mathrm{Rp} 77.131 .713,00$. Nilai BCR kelas usaha pinus 1,24, sedangkan kelas usaha damar 1,03. Selain itu, nilai IRR kelas usaha pinus $17 \%$ dan nilai IRR kelas usaha damar $13 \%$.

\subsection{Saran}

Hasil penelitian ini dapat menjadi bahan pertimbangan bagi PT Perhutani untuk merubah kelas perusahaan damar menjadi kelas perusahaan pinus, karena dapat meningkatkan nilai ekonomi yang lebih tinggi.

\section{Ucapan Terima Kasih}

Penulis mengucapkan terima kasih kepada Kepala KPH Malang, khususnya kepada Bapak Wahyu Tri Hadmojo, S.Hut selaku Kepala PHW IV Malang, dan Bapak Prisma Asiz selaku KSS Malang PHW IV Malang, KPH Malang yang telah membantu dalam penyelesaian penulisan jurnal ini. 


\section{Daftar Pustaka}

Antoh, F., Fatem, S.M., \& Tasik, S. (2015). Pemanfaatan damar oleh masyarakat di Kampung Bariat Distrik Konda Kabupaten Sorong Selatan. Jurnal Kehutanan Papuasia, 1(1), 53-62. DOI: https://doi.org/10.46703/jurnalp apuasia.Vol1.Iss1.29

Arianti, D.O., Idham, \& Zainal, S. (2018). Pemanfaatan getah damar oleh masyarakat di Kelurahan Kedamin Hulu, Kecamatan Putussibau Selatan Kabupaten. Jurnal hutan lestari, 6, 464-472.

Riyanto, D.H., Waluya, U., \& Pahlana, H. (2012). Kajian evaluasi lahan hutan jati sistem bonita di Kesatuan Pemangkuan Hutan (KPH) Cepu. Jurnal Penelitian Hutan Tanaman, 9(1), 43-50.

Efendi, D. (2016). Kajian kelayakan model pembangunan hutan tanaman rakyat pola mandiri berbasis agroforestri. Jurnal Hutan Tropis, 4(2), 120-130.

Gaol, M. (2020). Analisis faktor-faktor yang mempengaruhi harga getah pinus di Desa Parsingguran II Kecamatan Pollung Kabupaten Humbang Hasundutan. Universitas Sumatra Utara Medan. Skripsi

Herianto, N., Wibowo, A., \& Garsetiasih, R. (2010). Potensi karbon pada hutan tanaman tusam, mahoni dan jati di Jawa Barat dan Banten. Jurnal Penelitian Hutan Tanaman, 7(3), 147 154.

Ikramatoun, S., Khairulyadi, \& Riduan. (2020). Pemberdayaan masyarakat melalui pengelolaan hutan pinus di Kecamatan Linge Aceh Tengah. Jurnal Sosiologi Agama Indonesia, 1(3) 238-249.

Inayati, A.M. (2015). Produktivitas penyadapan getah pada tegakan pinus umur enam dan tujuh tahun. Manajemen Hutan, Fakultas Kehutanan, IPB University. Skripsi

Iriando, S. (2011). Penyebaran serangan kutulilin pinus (Pineus boerneri) pada tegakan pinus (Pinus merkusii) (Studi kasus di KPH Sumedang Perum Perhutani Unit III Jawa Barat dan Banten). Institut Pertanian Bogor. Skripsi

Ishak. (2018). Analisis pendapatan usaha petani penyadap getah pinus di Kelurahan Kahu, Kecamatan Bontocani, Kabupatan Bone. Universitas Muhammadiyah Makasar. Skripsi

Khotimah, H., \& Sutiono. (2015). Analisis kelayakan finansial usaha budi daya bambu. Jurnal Ilmu Kehutanan, 8(1), 14-24. https://doi.org/10.22146/jik. 8548

Krisnawan, M.A., Warsika, I.P.D., \& Nadiasa, M. (2015). Analysis of working capital requirement in the construction of houses using discounted cash flow method: (Studi kasus proyek perumahan green imperial putra residence). Latar Belakang Belaka, 19, 69-77.

Kusuma, P.T.W.W., \& Mayasti, N.K.I. (2014). Analisa kelayakan finansial pengembangan usaha produksi komoditas lokal: mie berbasis jagung, AGRITECH, 34(2), 194-202.

Majarani, D. (2006). Analisis prospek kelas perusahaan pinus (Pinus merkusii Jungh. et de Vriese) di KPH Cianjur Perum Perhutani Unit III Jawa Barat dan Banten. Manajemen Hutan, Fakultas Kehutanan, Institut Pertanian Bogor. Skipsi.

Subarudi. (2014). Analisis kelayakan sosial, finansial dan pasar produk hutan tanaman rakyat: studi kasus di Kabupaten Dompu. Jurnal Penelitian Sosial dan Ekonomi Kehutanan, 11(4), 323-337. DOI: 10.20886/jpsek. 2014.11.4. 15

PHW IV Malang [Perencanaan Hutan Wilayah IV Malang]. (2018). Rencana Pengaturan Kelestarian Hutan (RPKH) Kelas Perusahaan Damar. PHW IV.

Perhutani. (2014). Pasar ekspor getah pinus. https://eppid.perhutani.co.id/pasarekspor-getah-pinus-sangat-besar/ 
Purbawiyatna, A., Kartodihardjo, H., Alikodr, H.S., \& Prasetyo, L.B. (2011). Analisis kelestarian pengelolaan hutan rakyat di kawasan berfungsi lindung. Jurnal Pengelolaan Sumberdaya Alam dan Lingkungan, 1(2), 84-92. DOI: $\quad$ https://doi.org/10. 29244/jpsl.1.2.84

Rohman, Warsito, S.P., Purwanto, R.H., \& Supriyatno, N. (2013). Normalitas tegakan berbasis resiko untuk pengaturan kelestarian hasil hutan tanaman jati di Perum Perhutani. Jurnal Ilmu Kehutanan, 7(2), 81-92.
Soedomo, S. \& Hariadi, K. (2011). Prospek Industri Hutan Tanaman di Indonesia. Bank Mandiri.

Sutojo, S. (2007). Studi Kelayakan Proyek. PT Pustaka Binaman Pressindo.

Wattimena, C.M.A., Pelupessy, L., \& Selang, S.L.A. (2016). Identifikasi jenis hama tanaman damar (Agathis alba) di Hutan Lindung Sirimau Kota Ambon, Provinsi Maluku. Jurnal Ilmu Budidaya Tanaman, 5(2), 95-100.

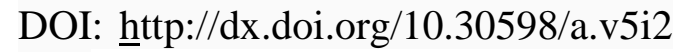
.187 